\title{
The Meaning of Female Passivity in Traditional Malay Literature
}

\author{
Rahimah Hamdan ${ }^{1} \&$ Shaiful Bahri Md.Radzi ${ }^{2}$ \\ ${ }^{1}$ Department of Malay Language, Faculty of Modern Languages and Communication, Universiti Putra Malaysia, \\ Serdang, Selangor, Malaysia \\ ${ }^{2}$ School of Malay Language, Literature and Culture Studies, Faculty of Social Sciences and Humanities, \\ Universiti Kebangsaan Malaysia, Bangi, Selangor, Malaysia \\ Correspondence: Rahimah Hamdan, Department of Malay Language, Faculty of Modern Languages and \\ Communication, Universiti Putra Malaysia, 43400 UPM Serdang, Selangor, Malaysia. Tel: 60-3-8946-8758. \\ E-mail: rahimahhamdan@gmail.com; rahimahh@upm.edu.my
}

Received: June 25, 2013 Accepted: July 8, 2014 Online Published: August 20, 2014

doi:10.5539/ass.v10n17p222

URL: http://dx.doi.org/10.5539/ass.v10n17p222

\begin{abstract}
In traditional Malay literature, women were often portrayed as individuals who were mentally, physically and spiritually weak. They were incapable of surviving on their own and could only hope to receive help and assistance from the main characters comprising men. In addition, the female characters in the genres of traditional Malay literature were 'silenced' by their authors when faced with certain situations without being given the opportunity to come forward to defend themselves let alone their rights. Their 'silence' was also related to their passivity in dealing with life. Thus, this paper will identify the female characters in several selected genres and analyse their level of passivity according to Bardwick's psychological perspective. The results of this study show that the 'silence' of traditional women marked their ingenuity in handling pressure from the Malay patriarchal society. The 'passivity' of this group was also meant to be a form of indirect aggression over their inability to establish their rights openly in society. This paper shows that the 'silence' of the women in traditional Malay literature does not mean they gave in willingly to every act committed against them, but it was also a 'subtle' resistance to the suppression by the patriarchal system as practised in the Malay community.
\end{abstract}

Keywords: manipulation, passive, patriarchal, gender, feminine

\section{Introduction}

Malay women were depicted in traditional Malay literary works as weak 'creatures' who were easily deterred, and were willing to sacrifice for the happiness and well-being of others (Krueger, 1984). This typical image of the traditional woman was formed by the gender system in the Malay community, which used certain codes to label the 'sexuality' of an individual. Women and men needed to follow certain patterns that had been put in place since the day they were born. This gender segregation code then led to certain classification of spaces in the Malay community that were often associated specifically with a particular gender. For example, 'public' spaces were controlled by Adam (men) while domestic spaces were ideal for Eve (women). This gave rise to terms such as 'kitchen maid', 'housemaid', 'housewife', and various other terms that refer only to women. This phenomenon was due to the power of the 'patriarchal system' that dominated the thinking, worldview and culture that greatly influenced every behaviour and action in the community. Thus, as long as there was a clear division between domestic and public spaces in a society, then women would continue to be subjected to patriarchal domination, where all power remained in the hands of the man as the head of the family (Rosaldo, 1974).

Due to the strong patriarchal dominance in traditional Malay society, women were often marginalized or their interests and contributions to society were ignored. Indirectly, most of the works in traditional Malay literature often placed women as 'second-class' people or as objects of ridicule in a story. They were not given the 'power' to protest against the actions and behaviour of men towards them. They were often 'passive', 'silent' or 'silenced' by the authors in order to meet the requirements of the patriarchal system. Characters such as Dang Bunga and Dang Bibah in Sejarah Melayu, for instance, were willing to be sent as gifts to Pasai together with other souvenirs. Similarly, Tun Kudu remained 'silent' as though she was prepared to be divorced on a whim so as to be remarried to an old nobleman for the sake of the prosperity of the city. Does this phenomenon prove that traditional Malay women had way whatsoever to defend themselves? Does that 'passivity' in women symbolize 
'indirect aggression' because of they were unable to establish their rights, let alone speak openly? Therefore, this working paper aims to analyse the 'passivity' of women from a psychological angle and to further prove that not all forms of passivity were in conformance to the gender codes of the society, but extended far beyond every action and behaviour.

\section{Social Gender System}

The gender system in the Malay community was very much influenced by religion, custom and culture. All these three elements were responsible for shaping the thoughts and viewpoints of the society, especially in the formulation of regulations or laws to ensure harmony in their lives for generations. Winstedt (1958) believes that the unique mix of several religions down through the ages, namely animism, Hinduism, Buddhism and Islam, with local and Western elements influenced the development of Malay customs and culture in the region. In fact, this complex combination confused the understanding of the Malay community with regard to customs. However, according to Al-Attas (1990), Islam emerged as the main religion in shaping the customs and culture of the Malays since its arrival in the 13th century AD. Thus, Islam has been considered as a guide towards a new era known as the 'modern' age because of its knowledge based on rationalism or reason as well as its social system, which emphasized individual freedom and liberation from the grip of irrational beliefs (Al-Attas, 1990). Therefore, the arrival of Islam in the Malay World was like a ray of sunshine and marked a paradigm shift in the entire social life of the Malays, covering their worldview, values, ethics and certain principles for survival. Those customs which were considered as not being contrary to Islam continued to be practised while those traditions which were obviously in conflict with the beliefs and principles of Islam were abandoned, or if there were any that could be further improved, they were given a fresh Islamic image. Thus, this explains the strong links between Islam and the customs, which played an important role in forming and shaping the ideology of gender relations among the Malay community.

Islam has established that the role and status of women is to 'complement' the men. The creation of Adam and Eve sent a clear message to the Malay community that men and women are mutually complementary and need each other. According to Islam, women are perfect human beings, just like the men (Al Quran, 4:1). Nevertheless, for the Malay community, the men are in a more dominant position than the women. They relate this to the creation of Adam and Eve and the biological nature of both genders. For example, men are believed to be physically stronger than women. On the other hand, women are endowed with a gentle nature and are more emotional than men. Indirectly, this difference would form the basis of gender relations in the Malay community because if this 'gender order' was violated an individual would be considered as a 'deviant', and in fact, might even be disowned by the family and cease to be a member of the community (Phelps \& Austin, 1975).

The Malay community saw women as being weak and highly dependent on the men. As such, the duties of women were confined to the domestic domain alone. However, there were certain qualities that were only possessed by women which allowed them to step out of the domestic domain if they possessed specific skills that were needed by the members of the community. The job of a midwife and healer, for example, afforded women an opportunity to move about freely according to the needs of the society (Karim, 1992).

The power of leadership in the Malay community, whether formal or informal, often rested on the shoulders of men. They believed that men could maintain good social relationships and were able to control the spread of gossip that could undermine moral and ethical values. This was strengthened by the values of Islam, which stressed on men as leaders (Al Quran, 34: 4). Furthermore, men were said to be more rational in their judgments than women. The statement that 'women are less moral' if given power was also reviewed by Bukhari al-Jauhari in Taj al-Salatin (Mahkota Raja-raja). This was evident in Malay historiographical works such as Hikayat Patani and Bustanus Salatin, which mentioned that the city-state was also governed peacefully by women rulers. However, the authority of these women rulers was constantly overshadowed by the men, where their nobles played the important role of 'policy makers' and the rulers simply had to give their assent. It was made very clear that the Malay community strongly supported the patriarchal system, which gave preference to men for any type of work. In fact, Western scholars, such as the psychoanalyst, Freud, also glorified 'patriarchal domination' in life by labelling women as creatures who were envious of 'the masculinity of the male sexual organ'. Therefore, Bardwick (1971), citing Freud's opinion, agreed that women did not deserve to be leaders because they lacked discretion and every decision of theirs was influenced more by emotion and compassion.

Gender roles were determined by the Malay community from the time when their children were still at an early age. Daughters had to devote part of their time to helping their mothers with domestic chores while the boys did heavy work in the public domain. It is clear that gender roles were nurtured from the start. These differences would shape the roles and responsibilities of the children when they grew up. This view was supported by 
Bardwick (1971), who was of the opinion that the psychology of women was a mystery as the 'feminine character' depended on several factors, namely the biology, anatomy and the social conventions of the time.

In this regard, it is clear that the 'passivity' of women that caused them to be easily manipulated and dominated by men or circumstances was due the effects of various factors around them that had been nurtured in them since childhood. This phenomenon caused women to use that 'passivity' for a variety of purposes, whether it was to escape the pressures of life, as an art to manipulate men or just to give in to everything that was done to them.

\section{Passivity in Relation to Manipulation and Domination}

Manipulation comes from the English word 'manipulate' which means an action using a particular method to influence an individual into performing a task or acting as required (The Chambers Dictionary, 1999, p.978). Manipulation also carries a negative connotation because of its ability to influence other individuals with specific intentions. This is a 'cancer' in a relationship whether in a marriage, friendship or community. Indeed, any relationship, whether in a marriage, family circle or friendship, should be fostered in an honest and sincere manner to ensure a peaceful relationship. On the other hand, if 'manipulation and domination' are involved, then certain individuals are bound to suffer oppression, misery and pain as a result of the actions of other individuals. Meanwhile, 'domination' in Malay society refers to the act of controlling various aspects of life, especially in relation to the issue of the 'rights' and 'power' of men over women. The difference is that manipulation only involves indirect aggression as an way to get whatever one wants by exploiting others, whereas 'domination' is quite a 'hard' action as it involves 'dropping' certain individuals (women) from continuing to enjoy the same rights as men. Bardwick (1971) believed that the dominant power of men in the society was one of the reasons that the activities of women were restricted to the extent that their personalities were affected. Accordingly, due to surrounding forces controlled by the gender system, which hinged on religion, tradition and culture, traditional Malay women were often categorized as individuals who were passive in their actions. However, the question arises as to what was the purpose of the authors in sketching that 'passivity' onto the female characters in traditional Malay literary works?

The level of 'passivity' of a person is measured based on 'activity' and 'aggression'. In general, 'passive' is defined as the expectation of getting what one wants where the manifestation of the ego is very weak in capturing, weak in integrative capacity, has very few alternatives for controlling the disappointment or trauma that strikes, and fails to control the degree of childishness that is inherent in every individual (Bardwick, 1971, p. 124). Bardwick (1971, p. 14) held that there are three levels of 'passivity' in an individual:

i. Very passive, that is incapable or having no desire to voice one's feelings even to a very important person in one's life. This is due to a loss of self-esteem.

ii. Overtly passive and subtly aggressive.

iii. Healthy passivity, where the woman reacts intelligently to disappointments.

However, 'passivity' is highly dependent on the emphasis that is given to it. Passive, as defined by Deutsch (1944), does not mean that no activity is being carried out, emptiness or no movement, but rather a more 'subtle' action with a specific interest or what is known as 'indirect aggression'. Hence, there are several types of 'passivity' by Bardwick (1971), namely:

i. Passive meaning agreeing or openness

ii. Passive meaning willing to be dominated by an individual out of love

iii. Passive as in having connotations of aggression in a 'subtle' form (indirect) that is usually directed against other women on the grounds that the relationship with men is very meaningful

iv. Passive as in having connotations of manipulating other individuals into doing a job that can be done on one's own because this 'passivity' is "a lack of outward aggressive behaviour, with the use of a passive-aggressive technique in order to manipulate and dominate". This type of passivity is "helpless choicelessness' especially in relation to cultural expectations. Since the community cannot accept women who are active and aggressive into its circle, women prefer to use their 'passivity' and 'femininity' in order to manipulate.

v. Passive as a manifestation of frustration but with a more compromising attitude (only express frustration within oneself).

vi. Passive also meaning 'quiet' or 'reserved'. 
Based on Bardwick (1971) six 'passive' categories above, this study will only select several categories and link them to examples of women in traditional Malay literature texts, namely passive and agreeing, passive because of willingness to be dominated by an individual out of love, passive for the purpose of manipulating, and passive as a manifestation of frustration. A review of the genres of traditional Malay literature turned up several female characters that fitted into those 'passive' categories.

\subsection{Passive and Agreeing}

In reality, there were many women in traditional Malay literature texts who acted passively by agreeing to whatever was done to them without any protest or attempt to defend their rights. If they were given a 'voice' by the author, it was only to fulfil the needs of the moment and particular interests. In fact, their presence in the works only sanctioned the patriarchal authority governing the life of the community. Historiographical genres such as Sejarah Melayu described Princess Syahrul Bariyah (daughter of Raja Kida Hindi) as the starting point for the chronology of the Malay Sultanate of Malacca when she married Alexander the Great, the King of Macedonia, who had conquered India in the expansion of his realm. She was described as a passive person who, in obedience to her father, Raja Kida Hindi, married the conqueror (Alexander the Great) of their country. Without her objection or consent, she was married to the conqueror of the state as a symbol of 'mutual understanding' and friendship over the defeat of India at the hands of the Macedonians. According to Feil (1984, p. 29), the exchange of women was a sign that the social ties between two parties or cities had been officially sanctioned. Consequently, not much was said by Princess Syahrul Bariyah except for one sentence when she wanted to inform her father that she had not had her period for two months (Sejarah Melayu, 1986, p.7). The question is why did the author play up the story of Princess Syahrul Bariyah not having had her period for two months? What was the significance of this in the Sejarah Melayu? This was merely to prove that the Malay dynasty in Malacca originated from the world's greatest king, Alexander the Great. This Indian princess was just the 'medium' in extending this great king's dynasty to the Malay world. Accordingly, the author only introduced one sentence out of the mouth of this princess as a sign that King Alexander's 'offspring' had arrived. She showed no other sign of protest or complaint about being forced to marry. Her opinions and feelings were completely ignored and in fact, without hesitation, Alexander the Great followed his father-in-law's request to leave his wife who was two months pregnant at that time. This clearly showed the low value of women in the eyes of men, let alone the conqueror of the world. Just as 'when the sweetness is gone, the pulp is thrown out', Princess Syahrul Bariyah was forced to agree with all the living arrangements made by them.

It can be seen here that the woman was only exploited to fulfil the 'sexual demands' of a man who was not responsible for building a marriage with a princess of one of his conquered states. The passivity of Princess Syahrul Bariyah seems to imply that she agreed with the action of her father and her husband in exploiting her for the sake of national peace besides proving her 'femininity' as a traditional woman who simply consented without protest to whatever 'masculine' acts were committed against her. Was it because her husband was a great man that she should have considered it an honour to be pregnant with 'his child'? Was this also why the coming and going of her husband at his whim and fancy could not be questioned? Such was the manipulation of women by men that they were forced to agree without questioning the actions of the men. As stated by Freud and quoted by Bardwick (1971, p. 5) "[...] this world is dominated by men who recognise the penis as a source of power".

Hikayat Banjar is a historiographical genre which also illustrates the passivity of the female characters, who simply agreed without protest to the actions of men in their lives. Princess Tunjung Buih was a mythical princess who appeared in many Malay historiographical works such as Sejarah Melayu, Hikayat Banjar, Salsilah Kutai, Hikayat Merong Mahawangsa and Hikayat Raja-raja Pasai. Her uniqueness was revealed when she was also linked to the chronology of the descendants of the Banjar rulers. According to Hikayat Banjar, this princess only appeared after Lambu Mangkurat's spiritual retreat in his quest to find a true king (native) to rule the country of Banjar. Although Banjar was ruled by a queen, this was in name only as all matters of state were handled by the nobleman named Lambu Mangkurat. This was evidence of Malay patriarchal power because the woman was only a symbol of the power of government while the reins of power remained in the hands of a man.

Princess Tunjung Buih was described as a passive person because she did not object when she was used as a mere 'symbol of government' by Lambu Mangkurat and Ampu Mandastana, the son of the founder of Banjar. Her passivity was obvious when she was not given a voice by the 'author' such that it looked as though she approved of the murder of her nephews (the sons of Ampu Masdatana) by Lambu Mangkurat due to a misinterpretation of the action of the princess in tossing Nagasari flowers and betel nuts to attract the attention of her nephews, who were playing around the castle. Lambu Mangkurat assumed that Princess Tunjung Buih was interested in marrying her nephews because in the Malay community betel nuts had connotations of a 'proposal'. 
Hence, after witnessing the incident, Lambu Mangkurat thought Princess Tunjung Buih wanted to marry her nephews, so he killed the two sons of Ampu Masdatana. If she had any power, Lambu Mangkurat's misconstrued action was definitely a slap in the face for the princess. But the author 'silenced' this female character so that she appeared to approve of Lambu Mangkurat's cruel act.

Princess Tunjung Buih was said to be passive because she only spoke on three occasions in Hikayat Banjar namely when she asked for various preparations to be made to welcome her from the river during her first introduction, when seeking to be married to a husband, who also appeared after a spiritual retreat, and when she called Lambu Mangkurat to present Nagasari flowers and betel nuts to her nephews. Apparently, women were still being exploited and men continued to dominate the situation even though a woman was holding the highest position in the country's system of governance.

The Oral Literature genre also featured a line-up of passive female characters just waiting to be rescued, who agreed with everything that was done to them, such as in Hikayat Langlang Buana, where Princess Dewi Kesuma was portrayed as following all the instructions of her father without being given a chance to speak or choose according to her own wishes. Many men were captivated by her beauty until her father (Maharaja Puspa Indera) decided to build a castle in the middle of a lake so that his daughter would be protected from her male admirers. This action curtailed her freedom and it was as though she was living in a 'golden cage'. However, Princess Kesuma Dewi remained silent as though consenting to her father's decision to torment her soul in such a manner. In fact, she had to agree with her father's choice of a husband without being given a chance to make her own choice. This was the reality of the traditional woman's life, where she was restricted in all her actions and words. So also with Hikayat Raja Donan, Hikayat Raja Dondang, Hikayat Anggun Che Tunggal, Hikayat Malim Dewa, and Hikayat Parang Puting, which had a line-up of passive women who simply followed the arrangements made for them.

\subsection{Passive Because of Willingness to Be Dominated by a Beloved Individual}

Bardwick (1971, p. 123) defined this passive category as willingness to be dominated out of love. This means that the women who were included in this passive category were willing to be treated in any way by a beloved individual, even if the actions of the loved one were intended to suppress or manipulate them. The individuals concerned kept silent as a sign of the purity of their genuine love for their beloved.

A search of the historiographical genre, Sejarah Melayu, turned up the character of Tun Teja Ratna Benggala, the daughter of Bendahara Inderapura (Pahang), who was betrothed to be married to Sultan Abdul Jamal. News of the beauty of the Bendahara of Pahang's daughter spread until it reached the ears of Sultan Mahmud Syah, who had just mourned the death of the queen (mother of Sultan Ahmad) and at the same time had failed to woo Princess Gunung Ledang. Thus, Hang Nadim was given the responsibility of escorting Tun Teja to Malacca to marry their ruler, Sultan Mahmud Syah. At that time, Tun Teja, who greatly admired the prowess and wisdom of Hang Nadim, was unaware that feelings of love were being kindled that would lead to the destruction of her future at the hands of the mighty hero of Melaka. Sejarah Melayu portrays the Bendahara's daughter as a passive individual with all the typical characteristics of a traditional Malay woman. Because of love, Tun Teja was prepared to leave her family and tarnish her reputation by breaking off her engagement to Sultan Abdul Jamal. Tun Teja's action in running away from her home was like 'rubbing coal on the face' of her family, who were of royal descent. Although she had been put under the spell of a 'magic potion', Hang Nadim was not solely to blame for what happened in the early stages of their introduction to each other because, after all, it takes two hands to clap. Hence, Tun Teja would rather be dominated by the 'purity of her love' for the man of her dreams until she was willing to hurt many people. She was unable to stop herself from 'loving' another man even though she was already betrothed to someone else. Tun Teja was a 'passive' woman who simply succumbed to love until she was willing to be dominated by a man in order to prove her love.

Hikayat Seri Rama also featured a passive female character who was forced to sacrifice in order to prove her love and loyalty to the man she loved. The Goddess Sita (Hikayat Seri Rama) was prepared to enter into the fire to prove her chastity to Rama. This action by the Goddess Sita was rather aggressive even though fire is considered as something sacred in Hinduism. However, on the one hand, she kept to the typical image of the passive traditional woman, whose fate was determined by the actions of men. The female characters could do nothing in the face of accusations or slander, more so when these were coming from the men they loved. The proof of this was that Sita still accepted and forgave Rama after he realized that he had made a mistake.

\subsection{Passive for The Purpose of Manipulating}

Women in the traditional period were bound very much to the demands and gender codes of their community. The ideal woman should be gentle in nature, submissive, loyal and maintain her feminine identity to avoid being 
considered as a 'deviant' by the community. Hence, women often used 'subtle' means so that their passivity and silence in the face of male oppression could be defended in a discreet manner. So, passivity not only meant a 'high rate of dependency' on the men but 'passivity' was also 'one of the ways to manipulate' certain individuals (Deutsch, 1944). For example, the mythical character, Princess Gunung Ledang, was one of the passive characters in Sejarah Melayu. She was said to be passive because she did not react aggressively after learning about a marriage proposal coming from Sultan Mahmud of Malacca, who was known to be a womaniser (Sejarah Melayu, 1986, p. 214).

Princess Gunung Ledang's passivity did not mean that she agreed to the marriage proposal but rather she subtly rejected the suit by making several unreasonable requests. The Sultan of Melaka agreed to meet her demands, thus indicating that he was willing summon the services of all his people. For example, among her impossible requests were that a golden bridge be constructed from Gunung Ledang to Melaka, and that several jars be filled with young betel nut juice and human tears. The king was not bothered that his people were burdened by these requests, but when the demands touched on the safety and interests of the king (a bowl of Raja Ahmad's blood) then he renounced his intention to marry the mythical princess. Indirectly, this indicates that Princess Gunung Ledang successfully manipulated the power of the patriarchs, who would do anything to satisfy their sexual desires.

Tun Fatimah, in Sejarah Melayu (Sulalatus Salatin), was another woman who used her passivity to manipulate her husband (Sultan Mahmud Syah) in a subtle manner. Her termination of several of her pregnancies was proof of her silent protest because of the hatred she bore towards Sultan Mahmud, who had murdered her father and family members. She could not refuse to marry the Sultan because such an action would be treason on the part of a Malay citizen. Thus, Tun Fatimah use the most discreet way (indirect) to subtly take revenge on the sultan by aborting every pregnancy. Her actions saddened him immensely and the sultan repented of the atrocities he had committed. Tun Fatimah's reason for her actions was that if she had a son, he would most likely not be appointed as the Crown Prince (Sejarah Melayu, 1986, p. 265). Finally, Sultan Mahmud Syah promised that if Tun Fatimah gave birth to a son, he would be installed as the Crown Prince to replace him. Indirectly, 40 days after her son (Raja Ali) was born, he was installed as the Crown Prince with the title Sultan Alauddin Ri'ayat Syah. Evidently, Tun Fatimah's passivity succeeded in manipulating Sultan Mahmud Syah into appointing her son as his successor, by-passing her stepson, Sultan Ahmad Syah and his younger brother, Raja Muzaffar. The phenomenon of 'silent' manipulation by Tun Fatimah was consistent with the opinion of Gal (1991, p. 196) about "silence as a symbol of powerlessness, and silence as a strategy of power".

\subsection{Passive as a Manifestation of Frustration}

The final passive category is as a manifestation of frustration over the possession of low levels of externally directed activity or low levels of externally directed aggression. For example, Tun Biajid's wife was 'used' by Sultan Mahmud in the absence of her husband. She was passive and could not refuse to commit adultery with the king because he was the Sultan of Melaka and held the most power in the land. In fact, her husband was the sultan's trusted nobleman and she herself was the daughter of Hang Tuah, an eminent nobleman of Melaka. Finally, through no fault of her own, she was divorced by her husband, Tun Biajid, who did not want to be known as a coward for being married to a woman who had been violated by another individual. This innocent woman remained passive and accepted whatever punishment was meted out to her. Once again, the soul of this woman was tortured by having to receive a punishment for someone else's wrongdoing. The fact is such was the reality of life for a Malay woman living during the age of feudalism, where the highest power was in the hands of men and the king, as the ruling power, must be obeyed with unwavering loyalty.

Hikayat Raja-raja Pasai also portrayed female characters who were living in fear and frustration but could not do anything about the problems they encountered. Tun Takiah Dara and Tun Madam Peria were the two daughters of Sultan Ahmad Perumudal Perumal. Both these princesses were unable to do anything except to wait for their elder brother, Tun Beraim Bapa, to rescue them from falling victims to their father's 'lustful desires'. Certainly, their passivity was associated with their frustration because the person on whom they thought could be depended on and who would love them had crushed their hopes by turning on them. Furthermore, their brother (Tun Beraim Bapa) had to commit treason and risk his life to save them from their own father. These were some of the pressures experienced by women in traditional times coupled with social factors that made 'passivity' the best way for overcoming any situation. Most of the women in traditional Malay literature, such as Princess Selindang Delima (Hikayat Selindang Delima), Princess Lindungan Bulan (Hikayat Puteri Lindungan Bulan) and so on, were more passive in dealing with frustrations in their hearts because they were bound by social conventions which moulded that passivity. 


\section{Conclusion}

Traditional Malay women would rather be 'passive' than speak up for their rights because they were aware of the obstacles and consequences that they would have to face if they were to 'breach' the social code set by the community. Their courageous actions invited more harm than good. This phenomenon was caused by a gender mould as well as the 'world view' of the society, which was responsible for curbing the personal 'freedom' of those women. Traditional life required women to resign themselves to their situation without openly protesting and defending themselves. Although 'passivity' seemed to be the best way for women to face the problems plaguing them in the traditional period, there were also certain characters who, at the start of the narratives, were portrayed as passive and naïve but later ended up being aggressive. For example, Siti Zubaidah in Hikayat Zubaidah Perang China, Saidatul Badrul Muin in Hikayat Syamsul Anuar, the maiden in Hikayat Musang Berjanggut, Siti Sara in Hikayat Nakhoda Muda, Siti Zawiah in Syair Siti Zawiah and so on were able to undermine patriarchal domination. In fact, their actions could have also caused a 'gender deconstruction' because they were able to change the view of society of the 'strength and intelligence' of women, who were on par with the men of that period in this regard.

\section{Acknowledgments}

This work is supported by Universiti Putra Malaysia under the Research University Grant (RUGS).

\section{References}

Abdul, S. A. (Ed.). (1986). Sejarah Melayu (Sulalatus Salatin). Kuala Lumpur: Dewan Bahasa dan Pustaka.

Al Quran.

Al-Attas, S. M. N. (1972). Islam dalam Sejarah dan Kebudayaan Melayu: Suatu Mukadimah mengenai Peranan Islam dalam Peradaban Sejarah Melayu-Indonesia dan Kesannya dalam Sejarah Pemikiran, Bahasa, dan Kesusasteraan Melayu. Kuala Lumpur: Universiti Kebangsaan Malaysia.

Bardwick, J. M. (1971). Psychology of Women: A Study of Bio-Cultural Conflicts. New York: Harper and Row.

Bukhari al-Jauhari. (1979). Taj al-Salatin. Jakarta: Departemen Pendidikan dan Kebudayaan.

Cheah Boon Kheng. (1993). Power behind the Throne: The Role of Queens and Court Ladies in Malay History. Journal of the Malayan Branch of the Royal Asiatic Society, 66(1), 1-21.

Collins Concise Dictionary Plus. (1989).The Bath Press: Glasgow.

Deutsch, H. (1944). The Psychology of Women: A Psychoanalytic Interpretation. New York: Grune Stratton.

Feil, D. K. (1984). Ways of Exchange: The Enga Tee of Papua New Guinea. Queensland: University of Queensland Press.

Gal, S. (1991). Between Speech and Silence: The Problematics Research on Language and Gender. In M. di Leonardo (Ed.), Gender at the Crossroads of Knowledge: Feminist Anthropology in the Postmodern Era. Berkeley: University Of California Press.

Hashim, R. S. (2002). Out of the Shadows. Bangi: Universiti Kebangsaan Malaysia.

Karim, W. J. (1992). Women and Culture: Between Malay Adat and Islam. Boulder: Westview Press.

Karim, W. J. (2002). Sexuality and Domination: A Collection of Essays. Penang: KANITA, USM.

Krueger, D. (1984). Success and the Fear of Success in Women. London: Collier Macmillan.

Phelps, S., \& dan Austin, N. (1975). The Assertive Woman. California: IMPACT.

Rosaldo, M. Z. (1972).Theorical Overview. In M. Z. Rosaldo, \& L. Lamphere (Eds.), Women, Culture and Society (pp. 17-43).Stanford: Stanford University Press.

The Chambers Dictionary. (1999). Chambers Harrap Publishers: Edinburgh.

Winstedt, R. O. (1958). The Malays: A Cultural History. London: Routledge and Kegan Paul.

\section{Copyrights}

Copyright for this article is retained by the author(s), with first publication rights granted to the journal.

This is an open-access article distributed under the terms and conditions of the Creative Commons Attribution license (http://creativecommons.org/licenses/by/3.0/). 